\title{
FROM TRANSFORMATION TO IDIOSYNCRATIC MODERNISATION SHIFTING ANALYTICAL PERSPECTIVES ON THE RE-SHAPING OF CENTRAL EAST AND EAST EUROPE
}

\author{
Hans-Joachim BÜRKNER \\ Institute of Geography, University of Potsdam, Germany
}

\begin{abstract}
After two decades of studies on the transformation of Central and East European regions and societies, most scientific communities seem to have normalised their theoretical concepts and empirical approaches. Leaving former exceptionalist views on systemic transition, convergence and hybridisation, and heading for "business as usual" as found in any society integrated into the world market or exposed to globalisation, they presently give the impression that transformation studies are coming to an end. This paper undertakes a review of the past phases of transformation studies in order to identify research gaps and necessities of further research on social and regional development as influenced by inherited or hybridised structural and cultural elements. It makes a point in favour of abandoning the convergence debate for more context-sensitive analyses of social change and societal restructuring, in particular with regard to structural fragmentation and cultural hybridisation.
\end{abstract}

Key Words: transformation, modernisation, regional and urban development, pathways of development, post-socialism, post-transformation.

\section{Introduction}

The $20^{\text {th }}$ anniversary of the fall of the socialist systems in East, Central East and Southeast Europe marks an important branching out of a research field which has accompanied public discourse for a long time. During the past years, the general view on the phenomenon of transformation (or transition, as the terminology of Anglo-American social science has it) ${ }^{1)}$ has developed in a twofold way: One group of discussants envisage the transformation of centrally planned systems towards market economies to have come to an end several years ago. Therefore, they feel that research on transformation be outdated. Hence, it would be unnecessary to continue it in the long run. Another group point to the fact that, up to date, the 'old systems of the East' have kept leaving their imprint on newly globalising societies and new 'varieties of capitalism' (Hall/Soskice, 2001). As a result, many new structures would keep being influenced by the heritage of socialism, yet in a more indirect and sophisticated way (cf. Kornai 2006). At least, they would be composed of heterogeneous elements which cannot be fully explained by the older idea of a complete replacement of systemic elements. According to this group, it is justified to persistently raise questions about path dependencies, in particular

1) Whereas the international debate on post-socialism employed the term „transition“, European scholars tended to make use of the notion of "transformation" in order to indicate a substantial restructuring of society and the economy. While "transition" suggests a gradual change from an initial structure (i.e. the final condition the socialist systems were in) to the target structure of a full-fledged market economy of the U.S. American type, the basic idea being rooted in modernisation theory, the term "transformation" does not finalise possible developments. Accordingly, the "end of the journey" does not become anticipated, thereby reducing normative implications of analytical perspectives. 
about the passing-on of ideas, the significance of perpetuated institutions and patterns of behaviour, and the emergence of hybrid formations of social practice - oscillating between 'Western' modernisation, everyday resistance against the impositions of globalisation, and nostalgic re-inventions of tradition.

However, the debate is not only characterised by this basic philosophical controversy. There is even more tension due to very different interpretive frameworks, empirical foci and basic ways of conceptualising change. The individual concepts focus on such diverse issues as structural and socio-economic elements of change, socio-political elements which refer to state-society relationships, institutional and governance-related elements, and cultural items in different fields of social life. As these frameworks tended to develop mutually exclusive views on transformation, a number of research gaps have emerged which are still waiting for being bridged. In spite of the fact that many focused approaches lack a comprehensive understanding of transformation, the gaps they created virtually circulate around the fundamental controversial question of structural convergence vs. structural and cultural hybridisation.

This paper undertakes a short critical appraisal of the basic ideas, the changing orientations and the yields of transformation studies. Due to the limitations of this text format, it cannot be exhaustive or go into too many details. At least, it will line out the major periods of research which display distinct arrays of basic assumptions, theory building and problems under scrutiny (chapter 2). It will then give an overview over the most important achievements (chapter 3), followed by an account of the remaining gaps of empirical research and theory-building (chapter 4). The final chapter will sketch a number of important strands of future research and give hints at problems of social and economic differentiation which will require continued reference to the socialist and post-socialist past. It ends up in a postulate for becoming aware of the ever more sophisticated logics of post-transformational development which can only be understood if persisting traits of former historical stages of transformation are reconsidered.

\section{Stages of research on societal transformation, $1990-2010$}

During the 1990s, academic debates on post-socialist restructuring made use of any notion which promised to give apt descriptions of the enormous project of giving up centrally planned economies and introducing capitalist market economies. Very broad and general terms, such as transition, restructuring, transformation etc. were taken from other fields of knowledge in order to fit into the new frameworks of analysis centred on post-socialism. Contrary to the often inflationary usage of vague notions at the beginning of the 1990s, increasing attempts at producing more specific and precise definitions could be noticed after this initial period.

Within preceding debates of the social and economic sciences, 'transformation' originally denominated the structural change of a society, an economic system, a region, etc. For example, economic transformation had been used as a term which described structural changes within a system of production, e.g. from industrialisation via industrialism to postindustrialist modes of production (cf. Rosenberg/Birdzell 1987). Post-socialism increasingly cast a spell on terms such as transition or transformation. By 1995, their usage had almost become restricted to the issue of post-socialist transformation. From then on, 'transformation' was taken in order to describe the change of basic systemic elements of the economy and the society (Merkel 1994, Kollmorgen 1994), often connected with structural disruption, the co-existence of heterogeneous structural elements, the introduction of new formal institutions, the persistence of older informal institutions, the polarised reallocation of wealth, accelerating social mobility and social disparities, growing risks of life conduct, harsh confrontations of 
political ideologies (from reformist neo-liberal to restorative post-communist wings), the devaluation of individual and collective life experience, the change of social milieus, and increasingly controversial interpretations of everyday life (Delhey 2001).

Meanwhile, transformation, understood as a real world phenomenon affecting the whole of a society, has left behind the initial phases of radical rebuilding. Often, it remains visible or accessible only within specific domains of social, economic and political life. In East Europe, the mainstream of societal development seems to have entered a stage of conformity to worldwide tendencies of post-industrial diversification. Globalisation, economic and cultural flows, national or local intervention by global players, and even the recent global financial crisis seem to have similar effects on the East and West -up to the point where the general impression suggests a nivelling of structural difference. This tendency has been backed up by East Europe's advanced stage of integration into the global economy and the community of nations. The last rounds of European enlargement, i.e. the accession of Poland, the Czech Republic, Romania, Bulgaria, Estonia, Latvia, Lithuania, Slovakia, Slovenia and Hungary, have done one more thing in order to reinforce this impression.

Nevertheless, it cannot be overlooked that there is a tremendous diversity of persisting and aggravating problems of development as soon as individual countries and regions are compared. Even in case similar indicators and manifestations of social and economic problems are to be found, the individual causes and their connectivity are difficult to compare. Inconsistent tendencies of regional and urban development seem to govern the scene: demographic change and shrinking cities or regions (East Germany) stand in contrast to the new growth of metropolitan regions and the spatial concentration of economic power in few privileged regions (Poland, Czech Republic: see Dostal 2008, Jalowiecki 2008). The continued economic crisis, chronical undercapitalisation of middle sized to large firms and high levels of unemployment (East Germany) stand out against low levels of formal unemployment, boosting informal sectors and undercapitalisation of small-scale industries and services (Poland). These problems have their roots in differing points of departure to societal transformation, specific path dependencies and different forms of connectivity to globalisation (i.e. at national, regional and local levels; see Stark 1996; Sýkora 2008). The particular interconnections between the global and the local have been arranged in manifold ways, often depending from the nature of local post-socialist and post-transformational response to supra-local or global challenge. They have produced hybrid structural configurations between national capitalism, state control according to neo-liberal ideologies and the intrusion of globalised capitalism. This has not only brought up different political interpretations of capitalism and relevant institution building according to the 'varieties of capitalism' thesis $\left(\right.$ Cernat 2006) ${ }^{2}$. It has also invoked problems of multi-level governance and increasing chaos of political, economic and social intervention at different scales (Buksinski 2005, Lane 2005). This hybridisation has to be kept in mind when it comes to analysing problems which, at the surface level, seem to be shaped in a similar way - be it the ever-growing vulnerability of regions when exposed to global economic crises, the proceeding peripheralisation of de-industrialised regions, the hardening of negative images of regions and cities, or growing prejudice against economically 'unsuccessful' regional populations. All these phenomena have a more direct link to the outcomes of systemic change than current public debates within individual countries or at an international level (e.g. the European Union) might reveal.

2) The thesis of varieties of capitalism as developed by Hall/Soskice (2001) claims for the conceptual differentiation of models of capitalist production according to the prevailing mechanisms of economic coordination, e.g. market, hierarchy, cooperation or deliberation. Accordingly, various modes of capitalism between liberal market economy and coordinated market economy can be discerned. 
These considerations might be a surprise to those who envisage transformation as a finished historical episode. Nevertheless, this surprise does not come about by chance. It was prepared by the leading political rhetoric inherent to neo-liberal post-socialist rule (Smith/Pickles 1998: 2 ), as well as by basic questions put by transformation studies during the 1990s. Both were carried by the expectation that there would be a quick adjustment of the East and West, once a fitting institutional framework within the new market economies and their societies had been created (cf. Peter 1994).

However, it is obvious that the real world developments did not come up to this expectation. Economic performance, as well as regional, political and social structures, remained remarkably different (see Bertelsmann Stiftung 2005), not only in international comparison but also at the national level. This holds true even for best case scenarios. For example, the German case shows that massive financial West-East transfer and internal structural assimilation could not reduce the economic imbalance between the eastern and western parts of the country. Moreover, regional comparison has shown that the implementation of neoliberal political objectives and strategies of development was effected in a multi-faceted, complex manner. While the institutional structure was shaped according to Western formal models, these models became locally reinterpreted and embedded into diverging social practice (Smith/ Pickles 1998: 12).

Taking into account the diversity and multiplicity of change, it is natural that no dominant paradigm of 'transitology' could be established (Gans-Morse, 2004). In looking back, several stages of transformation research can be identified which produced different kinds of knowledge about the nature and the conditions of societal change in Central East, Southeast and East Europe. In short, these stages are:

Stage 1 - Modernisation theory (1990-1995). During this initial stage, the first impulse by political scientists, social scientists, economists and geographers was to relate back to available theories of social modernisation, such as Parsons' (1967) or Lipset's (1959) concepts (cf. the critical appraisal by Müller, 1995). In practice, new modernisation theory was shaped in analogy to the body of political modernisation theories which had been discussed some decades ago with respect to industrialised capitalist societies (e.g. in South Europe) as well as to developing countries (e.g. in Latin America). Here, the breakdown of an older regime had been linked in theory to a compelling transition to democracy and liberalised market economy (Schmitter/Karl 1991), followed by democratic consolidation. Facing the need to theorise societal change after socialism, the basic assumption was that there would be a convergence of structures between East and West (Zapf, 1994; Outhwaite/Ray, 2005: 177 ff.). In particular, Eastern societies would take over the model of full-fledged, globally embedded capitalism, thus catching up on a development experienced by the countries of the Triad (Europe, U.S.A., Japan) before ${ }^{3)}$. Accordingly, mainly impediments to, and aberrations from, the characteristics of the models of reference where thematised and investigated. 'Defective' economies, originating from persisting elements of state-led organisation and practice, incomplete

3) In Germany, the state-led, top-down transfer of institutions produced a strong urge on scholars to focus on East Germany's preconceived adaptation to a fixed set of development targets (Pollack 1996: 416 ), thereby shading off the interplay of general aspects of social change (e.g. those which can be attributed to globalisation, new consumerism, individualism etc.). It also caused a normative bias on economic growth and the stabilisation of regional population numbers in East Germany. Accordingly, a major analytical focus was on coping strategies by individuals and groups when confronted with defective structures created by transformation (e.g. deindustrialised cities and regions). In a similar way, population loss and "shrinking" cities were investigated against the backdrop of pending disasters connected with post -socialist modernisation (cf. Oswalt 2005). 
deregulation and liberalisation, or caused by corruption and criminality, were a favoured topic of the day. Also, different pathways of development (e.g. the 'big bang' shock therapy vs. 'slow and steady' gradualism) were attributed to varying models of political rule and governance (from below and from above), including their inherent failures (Abel/Bonin 1991, Beyme 1994).

Stage 2 - Plurality of theories (1995-2000). Increasing criticism of modernisation theory as being too deterministic and normative (Müller 1996) triggered a fanning out of theoretical perspectives relevant to transformation research. They covered the following conceptual fields:

- institutional theory, with a special focus on post-socialist pathways of development, the path-dependency of institutions and policy-making, and the distinct logics (German Eigenlogik) of the trajectories of various societies and regions under conditions of systemic change (Grabher 1994b, Stark 1996, Hausner et al. 1995, Rudolph 1995 Stölting 1997, Tatur 2004);

- $\quad$ evolutionary economics and network theory, explaining for the implementation of new branches, emerging enterprise structures, inter-firm relationships and the specific adaptations by old and new networks to changing conditions of post-socialist reconfiguration (Grabher/Stark 1997a);

- $\quad$ political economy, regulation theory and new systems theory which maintained the persistence and subordination of 'inherited' structural fragments under a new logic of capitalist hegemony, emerging economic disparities and socio-spatial inequalities (Smith/Pickles 1998, Smith/Swain 1998, Krätke 1997);

- theories of contingence which envisaged the new mixtures of 'imported' and 'autochthonous' structural elements, institutions, logics of agency etc. as being part of a hardly predictable, incremental process of differentiation (Müller 1996); in their view, transformation was susceptible to chance, chaos and error.

Stage 3 - Recent conceptual diffusion (since 2000). This phase is characterised by the decreasing analytical relevance of the issue of transformation. Instead, big secular trends such as globalisation, Europeanisation, demographic change, migration and the global-local hybridisation of everyday culture became dominant in regional and urban studies on the former socialist world (as few examples out of many: Hamilton et al. 2005, Mansoor/Quillin 2006, Steinführer/Haase 2007). Occasionally, these studies were augmented by cursory conceptualisations of the relevance of social, local, regional and national peculiarities referring back to the former systemic overthrow. In this optic, transformation was reduced to a marginal framing condition of social change. Casual discourses about 'post-transformation' indicate an increasing discomfort with strands of thought which emphasize the role of structural persistence and continuity - this kind of thought has often been felt to be overly historicising (Lutz 2003: 291 f.). Further irritation was produced by those scientific communities (e.g. in Germany) which established transformation as a niche concept which was not sufficiently tied to mainstream debates of globalisation and post-modern social change (cf. synopses of the status quo by Beyme, 1999 and Merkel, 1999). As a result, to many beholders the concept seemed to become increasingly outdated the longer the single event of the fall of the iron curtain dated back.

In spite of the relative devaluation of transformation as a secular process of major interest, the contested notion of convergence continues to inform a number of recent studies on political change and regionalisation in Central and Eastern Europe. Here the conviction lingers on that transition would imply an inevitable move from state socialism to a new condition of modernity which is more or less based on Western notions, for example in the debate on Europeanisation. Based on the idea that Europeanisation could be conceptualised as a 
variation of the Hägerstrandian model of diffusion, implying the convergence of norms, agendas and policy instruments, the discussion suggests a process of adaptation and absorption of Western values (see Schimmelfennig and Sedelmeier 2004). However, in contrast to stage 1, crude determinist thinking along the 'Western modernisation' line has been increasingly challenged during the past decade by the obvious peculiarities of local social practice. For example, EU policies and their imperatives are often susceptible to strategic reinterpretation and agenda-setting for local political purposes (for the Czech Republic and Slovakia, see Brusis 2005). The growing response by locally informed and contextually sensitive scholars not only indicates a ripened, more sophisticated understanding of transformation. It also makes a point in favour of the idea of idiosyncratic modernisation: It takes external political intervention (here: by the EU) for nothing more than a trigger for rather autonomous and logically independent local or national policy-making.

\section{Achievements made by transformation studies}

When accounting for the main achievements of transformation studies, a special focus has to be laid on the relationship between theory building and empirical work. During every stage, description played a major role, not only in geography and economics but also in social analysis and history. Making diachronic accounts of the structural change of the societies, cities and regions of East and Central East Europe, and making comparisons between different states of affairs concerning specific aspects of transformation - these were the key endeavours of research which contributed much to the knowledge of the varieties of sectoral developments as well as to the modelling of various pathways of development. In contrast, theory building was treated in rather diverse ways.

During stage 1, theoretical debates were conducted in a fairly general, often even abstract way. Modernisation theory obviously did not relate too much to empirical evidence. As opposed to the theoretical superstructure, empirical descriptions were often set apart in a loose manner, combined with ad hoc interpretations of structures and developments. However, during stage 2, the broadening scope of analysis and a growing variety of theoretical approaches allowed for more convincing connections between theory and empiricism. The unfolding number of foci of analytical interest can be read from the following list of major objects of study:

- $\quad$ privatisation, institution building and their effects on political and economic restructuring (Csaba 1994, Seibel 1997);

- new entrepreneurship, small and medium-sized enterprises and economic networkbuilding (Grabher/Stark 1997b);

- $\quad$ regional economic change and new regional disparities, effected by transformation-specific deindustrialisation, privatisation and the selective impact of globalisation (e.g. foreign direct investment, joint ventures and economic cluster building in the big agglomerations and the Western border regions of the former socialist countries) (Barta 1994, Buckwater 1995, Bürkner 1996, Grabher 1994a, Górzelak 1996, Górzelak 2000, Heller/lanoş 2004);

- change of urban structures, in particular in connection with emerging capitalist real estate markets and housing markets, the changing importance of large ex-socialist housing estates and private suburban building activities (Fassmann 1994, Lowe/Tsenkova 2003, Stanilov 2007);

- changing political border regimes and their effect on border regions and border towns (Aschauer 1995, Bürkner 1994, Krätke 1996, Krätke et al. 1997, Eskelinen et al. 1998 Matthiesen/Bürkner 2001), in particular in connection with various modes of international cooperation and new types of regionalism under the aegis of the European Union (e.g., Euroregions which emerged at different points of time along the outer borders of the EU) 


\footnotetext{
(Scott/Collins 1997, Perkmann 2005, Scott, 2006);

- demographic change and regional rsp. urban shrinking (mainly population loss and its effects) in East Germany and some other peripheral regions (Witte/Wagner 1995, Philipov/ Dorbritz 2003, Franz 2004, Oswalt 2005);

- migration at different scales (regional, international, transnational) affecting the regions of East and West Europe alike (Baldwin/Venables 1994, Frejka 1996, Fassmann 1997, Heller 1998, Dietz 2002);

- $\quad$ living conditions of ethnic minorities, ethnic mobilisation and the changing political role of ethnicity (Barany 1998, Stein 2000, Vermeersch 2003, Heller 2004);

- increasing social mobility and social inequality (Ott/Wagner 1997, Duke/Grime 1997, Roberts 2003), gender conflict (Goldfarb 1997), new lifestyles (Ray 1997), new consumerism and their socio-spatial effects (spatial segregation, change of social milieus and urban neighbourhoods, gentrification, etc.) (Szelényi 2001, Ladányi 2002, Sýkora 2005 and 2009, Smigiel 2009).
}

Studies of varying degrees of empirical saturation contributed to a variety of disciplinary insights into sectoral developments, as well as into major trends of urban and regional development, involving a multitude of individual disciplines. Valuable as they were, they seldom were embedded in a larger analytical context which would have allowed for taking up initial research targets and questions, such as those which were established during stage 1 . For instance, integrative approaches and multi-level analysis which could deliver answers to the basic question about the nature of societal transformation as a whole, count among the rare and happy coincidences inside a scattered research scene. In a similar way, truly interdisciplinary approaches to basic issues of systemic change and social life remained rather uncommon.

\section{Analytical gaps}

In every phase, considerable analytical gaps originated as soon as the perspective of convergence became emphasized. A central aspect of the convergence thesis was the idea that it would be necessary to adjust 'dysfunctional' systemic elements to a pre-established model of the market economy and compatible democratic rule. Against the backdrop of such models, the status of achievement at a given point of time had to be defined in terms of suboptimal, mismatched or even defective structures (cf. Hopfmann 1993). The overall rhetoric of model-driven change allowed for implicit rankings of individual societies, regions and cities on their way to establishing 'proper' market structures and compliant modes of regulation. Tacit as this idea often remained, it turned out to be all the more effective in preventing non-finalised conceptualisations of societal change. Especially the 1990s witnessed severe difficulties to get rid of normative preconceptions and narrow anticipations of the future which had infiltrated many analytical concepts. Structural disruption due to the impact of 'free' market rules and liberalisation, fragmented restructuring, diversified institution building, cultural antagonism and, at the same time, cultural hybridisation were hard to address, at least from any other vantage point than the one of the convergence thesis.

It was left up to the beginning millennium to bring about a shift in optic: A growing awareness of the peculiarities of 'Eastern' development gave way to a broader acceptance of the insider's view on post-socialism. In his analysis of cultural landscapes of post-socialist cities, for example, Czepczyński postulated that it should mainly be a task for 'insiders' to gradually explore the interpenetrations of old communist forms and new free-market meanings, global influences and local icons (Czepczyński 2008). This task could only be realised during the last years. The scientific community increasingly became aware of considerable tensions between 
insider and outsider perspectives, and of the 'Western modernisation' pressure exerted both in political practice and academic theory building. Conceptual emancipation from this pressure has become tangible.

On the whole, it proved to be extremely difficult to find out about the peculiar logics which emerged somewhere between 'Eastern' and 'Western' interpretations of reality, between old certainties and new imponderabilities, between the adverse mentalities of social collectivism and economic individualism, between individual coping with global patterns of consumption while keeping up traditional elements of social practice, etc. And it was even more difficult to understand that these logics had a rhythm of occurrence, a half-life, and a context-dependent social significance of their own. Major problems of conceptualising transformation in terms of open-ended, non-finalised developments could be seen vis-à-vis the following analytical topics (a) $-(\mathrm{c})$ :

(a) Permanent economic crisis. The severe economic crisis following the demise of the socialist systems was envisaged as an inadvertent structural deficiency, rather than a logical outcome of the particular integration of East European regions into the world market. Therefore, the long-term nature of deindustrialisation, lacking substitution of the former industrial structure by new services and knowledge-based economies, and continuously high levels of unemployment were highly underrated. In many regions, economic restructuring resembled well-known patterns of peripheral industrialisation known from neo-fordist restructuring in West Europe. Prolonged workbenches and quasi vertically integrated networks of small and medium enterprises (SME) seemed to have been relocated to low-cost regions in East Europe over night (Grabher 1992, Krätke et al. 1997: 40 f.). During the 1990s, most headquarters of transnational corporations and important decision-takers remained in the old West European or transatlantic centres, leaving the new 'Eastern divisions' without power and influence. In spite of consecutive relocations of economic capacities to East Europe, the initial economic marginalisation was a throwback from which most Eastern regions did only gradually recover. Moreover, national economic policy largely contributed to creating unfavourable conditions for regional economies to compete at a global level. For instance, in the 1990s, East Germany was exposed to a policy of radical deindustrialisation which was meant to create a tabula rasa for global players. It also should produce a strong urge for renewing the economy. However, renewal took a rather long time after the total collapse of the old production structure, and it was successful only in a small number of urban regions where global stakeholders placed investments in favour of high-tech production clusters and globally interlinked services (e.g. in the agglomeration of Leipzig - Chemnitz - Dresden; Krätke/Scheuplein, 2001; Nuhn, 2001). East Germany's economy remained in a structural configuration which was decisively conceived and prepared by politics, in this particular case by policies of sporadic peripheral reindustrialisation, the experimental initialising of new industrial production clusters and the selective establishment of knowledge intensive services (Krätke et al. 1997, Heidenreich 2005). Since a large part of this development was based on jobless growth, labour markets remained in crisis, giving rise to several waves of out-migration of workforce and related brain drain (Bürkner/Matthiesen 2007). This configuration cannot be called defective or malfunctioning rather, it is part of the regular policy-sustained restructuring which global capitalism provides for undercapitalised peripheries and semi-peripheries of the world system.

(b) Urban and regional governance, new political participation and the civil society. Research on emergent forms of urban and regional governance often focused on ideas which were taken from West European or transatlantic governance studies. There was a general expectation that governance would come out according to Western modes of state formation, public-private partnership, grassroots-like negotiating and self-organising - once a suitable institutional 
framework had been introduced and democratic procedures had been put into practice. However, it is still unclear which kind of citizenship has emerged in East Europe and how its emergence can be explained (cf. Lewis 1997); at least it seems to differ considerably from the West European type of a civil society (Sagan 2009). Searching for well-known governance structures in a comparative perspective (Croissant et al. 2000) often prevented scholars from developing a closer look at political decision-making, especially at elitism and clientelism. Consequently, the role of the civil society for transformation was grossly mistaken. While the overthrow of the socialist systems was seen as an important achievement of an invigorated civil society after a long period of authoritarianism (Mansfeldová/Sabó 2000), its future significance as a driving political force was estimated according to this strong initial appearance. However, there is evidence that even in the early stages of transformation the population masses in the streets could be part of a media spectacle orchestrated by old elites in the process of migrating to leading positions in the new system (Gabanyi 1998). Whether politically autonomous or not, in later stages of transformation the civil society obviously lost its initial importance. In practice, in many regions there has been a virtual absence of larger civil society initiative as a basic social phenomenon. Instead, it has to be acknowledged that in most East European countries a different concept of the civil society was deliberately invented by the political class. Often, it takes the appearance of new patron-client forms of relationships (Korkut 2005). For example, many local initiatives, action groups, committees etc. were created by political parties in order to serve their specific interests while keeping up the public image of 'spontaneous' congregations of independent citizens (Dimitrova et al. 2007). Apart from taking immediate benefits from instrumentalising the population in this way, it proved to be advantageous for the political system to point out that there was an evolving civil society because the external image of the country would improve and the compatibility with EU accession requirements would be facilitated.

(c) Persistent cultural boundaries and seclusions as elements of everyday life. Socio-cultural niches within new post-socialist structures were often misunderstood as temporal phenomena which would gradually disappear during the process of making the market the guiding principle of social formation. For instance, old-style residential milieus which were preserved inside large socialist housing estates were often taken as a problem of time-lags occurring during modernisation. Alternative interpretations did not come up easily, such as the idea that there might be socio-spatial units (e.g., marginalised urban neighbourhoods and milieus, or peripheral regions) which remained untouched by overt external impulse to modernise, while their members tacitly adopted new ideas of social well-being, consumerism, political participation, etc. In many cases, visible indicators of modernisation and everyday mental orientations or informal institutions did not match (Tatur 2004). Taking these mismatches as signs of a time lag regularly resulted in crude misinterpretations of cultural hybridisation. For instance, Germany's urbanist debates of the early 1990s nurtured the myth of the unbroken popularity of large housing estates inherited from the socialist regime (Hannemann 2005: 146, Rietdorf 1997), sometimes mistaking economically caused spatial immobility of residents for lacking mental adaptation to available options provided by the new markets. In a reverse way, large numbers of residents leaving deteriorating apartment blocks after the model of 'single family homes in a suburban milieu' had been popularised became reinterpreted as the realisation of suspended aspirations for mobility (Franz 2000, Brabec/Sýkora 2009), often dating back to socialist times and old dreams of a better life. Only after one decade of similarly focused social analysis, a new awareness for cultural diversity and everyday cultural hybridisation emerged (e.g. in connection with groundbreaking milieu studies, see Matthiesen 2002), revealing that lifestyles, housing demands, milieu formation and other aspects of everyday life simply did not conform to one guiding logic (i.e. the logic of catch-up modernisation). 


\section{Gaps to be filled by future studies on transformation and post-transformation}

Public interest in problems of transformation significantly ceased at the beginning of the millennium. As a result, research on transformation lost its impact on public discourse. In addition, it became more difficult to fill the pending gaps of research. On the one hand, in many studies on social, economic and political problems of East and Central East European regions, the issue of transformation itself lost its weight as a point of theoretical interest. On the other hand, the dwindling public interest had a negative effect on available research funds. Thus, funding and research activities have continuously been on withdrawal. Nevertheless, regional disparities, social fragmentation, polarisation and problems of urban governance have increased in scope and visibility during the past years (Brusis 2001: $224 \mathrm{f}$.), demanding for intensified research and political action. Since regional trajectories and the outcomes of various sectoral pathways of transformation were often obscured or blurred during the seminal stages of transformation, there were fewer opportunities to convey detailed and differentiated empirical investigations than at present. Now, since many problems have been revealed in sufficient clarity and complexity, there are many good starting points for differentiated, multi-level studies which could fill relevant analytical gaps more easily than it was possible in the past.

Important persisting problems which still have a strong connection to the headline of 'transformation and outcomes of transformation' are:

- $\quad$ the growing impact of structural fragmentation on urban and regional development ("from transformation to fragmentation", see Smith 1999: $15 \mathrm{ff}$.); while rising economic disparities have been described in terms of a mosaic-like restructuring of space according to the production models introduced (Krätke et al. 1997: 407), in-depth investigations into the changing social and political significance of socio-spatial fragmentation are still missing (for cursory insights cf. Stenning 2005, Nagy 2005);

- the characteristics and variations of regional trajectories of development and related forms of governance; while there has been growing awareness of the peculiarities of individual trajectories, and of the impact of past trajectories on future path dependencies, the variations and the nature of dependencies stemming from initial periods of transformation have only marginally been investigated;

- the significance of informal or shadow economies for the stabilisation of formal economic sectors and for social status building; apart from some early speculations about the origins of new entrepreneurialism in informal fields of the economy and some empirical evidence about expanding small trade during the 1990s (Murrell 1993, Gabor 1997), detailed information about the emergence, the re-structuring and the social embeddedness of informal economies in East Europe is still missing;

- $\quad$ the significance of new elites for regional and urban governance; the body of literature on this issue is rather heterogeneous and miscellaneous (cf. Merkel 1999: $111 \mathrm{ff}$;; Bürkner 2003); while a number of studies were made on East Germany and on elite reproduction in the 1990s (Szelényi/Szelényi 1995, Higley/Lengyel 2000, Eyal et al. 1998), there is less empirical evidence with respect to recent developments in Central East and Southeast Europe;

- the significance of civil society for urban and regional development, especially in connection with problems of local participation; here, the question of lobbying and building political pressure capacities will be of major interest (Fischer/Pleines 2010); a recent study on the increasingly important role of civil society actors indicates one out of several possible future directions research might take (Scott/Liikanen 2010) - here, the establishing of informal networks in the process of Europeanisation and cross-border cooperation between EU member states and neighbouring countries has triggered 
processes of de-centralised political socialisation and pressure-making;

- the clash of old and new institutions at different levels of social action; here, the contradiction between formal institutions (such as legal frameworks and regulations, rules concerning formal political and administrational routines etc.) and informal institutions (i.e. everyday rules of action which become established by negotiation, social interaction and convention) still is relevant to social practice (cf. Tatur 2004); in particular, understanding the way formal institutions become interpreted, molded and re-shaped by informal practice will be a major way of coming to grips with present and future problems of urban and regional development;

- emerging social inequalities, following increasingly diverse regional patterns of economic growth and decline, exposedness of societies and regions to globalisation, cultural assimilation to the global, and other factors (Heyns 2005);

- the change of social milieus and other forms of community building under the impact of the restructuring of urban space and the ongoing decline of peripheral regions (see Wolfe 2000, Smith 2003); here, the upcoming focus on gender issues in East Europe will have to be developed with particular care (Fodor/Balogh 2010);

- $\quad$ origins and effects of hybrid everyday culture which might take different shapes along the extremes of melange and fragmentation: either by assimilating local, global, past and present influence as part of a universal global melange (Pieterse 2003), or by accumulating co-evolving yet separated or contradictory cultural elements, often represented by fragmented identities (Roman 2003).

Since many or most of these problems have their roots in post-socialism or even back in socialist times, it is clear that the present period cannot be exclusively addressed in terms of context-free, successful 'adaptations to the market' (cf. the staunch denial of path dependency by Wiesenthal et al. 2001: 16). Although the most spectacular changes have passed, the traces back to transformation and the peculiarities of hybrid social practice are strong influences of present economic restructuring and social differentiation (Kollmorgen 2005: $20 \mathrm{ff}$.). In this sense, the term 'post-transformation' should be established in order to describe a mode of modernisation which still is logically and structurally bound or indebted to post-socialism and the former pathways of transformation. Yet at the same time, post-transformation has to be treated as an open concept which accounts for the integration of heterogeneous elements of ongoing transformation of the whole society. At present, competing concepts are trying to theorise modernisation as a confluence of multiple transformations (including post-socialist transformation) which are present in all fields of societal development (see the concepts of 'post-post-transition', Buyandelgeryin 2008, or of 'hypertransformation', Binas 2008). However, an overly open concept might fall back into the trap of remaining unspecific and undertheorised as to the issue of post-socialism (Thomas 2008). Post-transformational studies will have to face the task of detecting the relevant traces back to post-socialism and incorporate them into interpretations and explanations of globalising regional societies. Only by means of working out the idiosyncratic nature of East Europe's modernisation, relevant and sustainable clues to future problem-solving will be found.

\section{Conclusions and Prospects}

Early political hopes for a quick adjustment of the societies and regions in the East and West did not come true. While the big regulations concerning legal frameworks, political constitutions, economic structures and formal institutions have come to conform to the major EU regulations and global market structures, the informal institutions, and also many formal arrangements below the level of the nation state, still make a tremendous difference. New path dependencies have initiated varieties of urban and regional development which entail their 
specific contingent logic. These varieties still await profound analytical reconstruction, especially in a comparative perspective. Nevertheless, public opinion as well as academic interest has turned to other issues of the day, leaving the question prone to disregard as to how the structural and cultural legacies of post-socialism and transformation should be treated.

For the academic research scene, this observation should be a reminder of the fact that a lot of important questions have only slightly been touched so far, if not ignored completely. As it now seems, the turning away of the scientific community from earlier modernisation theory has not been compensated by a coherent theory which is able to produce a sophisticated and sustainable view on transformation and post-transformation. Although postmodernism has restructured this field of research, rendering the early hope for "grand theories" an inadequate aspiration, there is no reason why the quest for coherent and comparative explanation and interpretation should be neglected. Giving up a critical, systematic and focused view on the outcomes of transformation would be too early for one thing, and, for another thing, even counterproductive in the long run (see Stenning/Hörschelmann 2008). There is enough reason to assume that obvious problems of urban and regional development, in particular the dynamics of social, economic and political conflict, and resulting fragmented development, will keep being influenced by the directions set in earlier stages of transformation. The longevity of trajectories once chosen, the structural asymmetries included, the contradiction between the institutions involved, persisting social practice, hybridised everyday culture, and many other aspects of development at different scales - all these phenomena cannot be explained in a convincing manner without explicitly referring to the category of transformation.

Detailed empirical reconstructions of social, economic and political developments in East Europe which reconsider the impact of transformation are still in demand. A reconstructive perspective which employs the insider's view instead of Western preconceptions of societal change would be an adequate answer to the challenge of path dependency and the emergence of new varieties of capitalism and democracy. Although a shift in orientation is gradually being felt, the "Western" bias is still there, often hidden under the label of European normalisation. Former exceptionalist views related to the issue of convergence have been replaced by political calls for Europeanisation and the compliance of new or future members of the European Union to general EU standards (cf. Pridham 2007). Following this call, academic endeavours such as the search for frictionless Europeanisation and structural normalisation according to the alleged requirements of globalisation or Europeanisation are increasingly competing with analytical positions aiming at carefully reconstructing the controversies, structural fragmentations, social disparities and peculiar mixtures of heterogeneous structural and cultural elements. In order to achieve a more unbiased account of social change as occurring within a specific historical context of global, national and local interchange, the 'insider' view of scholars who are members of the societies and the lifeworlds involved is very much in need (cf. the work of Czepczyński 2008).

Investigating social practice in a way which makes hidden 'legacies' and adaptations to changing social and structural environments transparent while developing an eye for the "multiple ways of being" (Buyandelgeriyn 2008) might be a promising method of dealing with the realities of post-socialist societies. Such a direction of social analysis then might rightly carry the label 'post-transformational studies'.

\section{References}

ABEL, I., BONIN, J., P. (1991), Two Approaches to the Transformation in Eastern Europe: The "Big Bang" Versus "Slow But Steady", Acta Oeconomica, no. 43 (3-4), pp. 213229. 
ASCHAUER, W. (1995), Auswirkungen der wirtschaftlichen und politischen Veränderungen in Osteuropa auf den ungarisch-österreichischen und den ungarisch-rumänischen Grenzraum, Potsdamer Geographische Forschungen, 10, Potsdam .

BALDWIN, R., VENABLES, A., J. (1994), International Migration, Capital Mobility and Transitional Dynamics, Economica, no. 61 (243), pp. 285-300.

BARANY, Z. (1998), Ethnic mobilization and the state: The Roma in Eastern Europe, Ethnic and Racial Studies, no. 21 (2), pp. 308-327.

BARTA, G. (1994), Foreign Investment in the Hungarian Economy: The Role of Transnational Companies, in: DICKEN P., QUEVIT M. (eds.): Transnational Corporations and European Regional Restructuring, Netherlands Geographical Studies, 181, Utrecht, pp. 131150.

BERTELSMANN STIFTUNG (2005), Bertelsmann Transformation Index 2006: Auf dem Weg zur marktwirtschaftlichen Demokratie, Gütersloh, Verlag Bertelsmann Stiftung.

BEYME, K. von (1994), Ansätze zu einer Theorie der Transformation der exsozialistischen Länder Osteuropas, in: MERKEL W. (ed.): Systemwechsel 1: Theorien, Ansätze und Konzeptionen, Opladen, Leske und Budrich, pp. 141-171.

BEYME, K. von (1999), Osteuropaforschung nach dem Systemwechsel: Der Paradigmawandel der "Transitologie", Osteuropa, no. 49 (3), pp. 285-304.

BINAS, E. (2008), Hypertransformation: Transformation, Entwicklung und Hyptertransformation. Auf dem Weg in eine Denk- und Forschungslandschaft, Frankfurt/M, Peter Lang (Görlitzer Beiträge zu regionalen Transformationsprozessen, 3).

BRABEC, T., SÝKORA, L. (2009), Gated Communities in Prague, in: SMIGIEL C. (ed.): Gated and guarded housing in Eastern Europe, Leipzig, Institut für Länderkunde, pp. 83-89 (Forum IfL 11).

BRUSIS, M. (2001), Institution Building for Regional Development: A Comparison of the Czech Republic, Estonia, Hungary, Poland, and Slovakia, in: BEYER J. W. J., WIESENTHAL $\mathrm{H}$. (eds.): Successful Transitions: Political Factors of Socio-Economic Progress in Postsocialist Countries, Baden-Baden, Nomos Verlagsgesellschaft, pp. 223-242.

BRUSIS, M. (2005), The Instrumental Use of EU Conditionality: Regionalization in the

Czech Republic and Slovakia, East European Politics and Societies, no. 19 (2), pp. 291-316.

BUCKWATER, D. W. (1995), Spatial Inequality, Foreign Investment, and Economic Transition in Bulgaria, The Professional Geographer, no. 47 (3), pp. 288-297.

BUKSINSKI, T. (2005), The Challenges of Globalization to Central and Eastern Europe, in: BUKSINSKI T., DOBRZANSKI D. (eds.): Eastern Europe and the Challenges of Globalization, Washington DC, Library of Congress Cataloging-in-Publication, pp. 23-42 (The Cultural Heritage and Contemporary Series IVA, Eastern and Central Europe, 27).

BÜRKNER, H.-J. (1994), Northwest Bohemia: A Central European Border Region in Transition, Boundary and Security Bulletin, no. 2 (1), pp. 84-85.

BÜRKNER, H.-J. (1996), Dynamik des sozioökonomischen Umbruchs in Ostmitteleuropa: Das Beispiel Nordwestböhmen, Kassel, Gesamthochschulbibliothek (Urbs et Regio, 64).

BÜRKNER, H.-J. (2003), Autochthonous and Western Professional Elites in East Central Europe: Socio-cultural Convergence in the Process of Transformation? in: Anuarul Institutului de Istorie al Academiei Române "George Barițiu" din Cluj-Napoca, Seria Cercetări Socio-umane, 2002-2003, Bucureşti, Editura Academiei Române, pp. 191-202.

BÜRKNER, H.-J., MATTHIESEN, U. (2007), Territorial Cohesion, Brain Drain and Digital Divide, in: SCHOLICH D. (ed.): Territorial Cohesion, Berlin, Heidelberg, Springer-Verlag, pp. 53-62 (German Annual of Spatial Research and Policy 2007).

BUYANDELGERIYN, M. (2008), Post-Post-Transition Theories: Walking on Multiple Paths, Annual Review of Anthropology, no. 37, pp. 238-250. 
CERNAT, L. (2006), Europeanization, Varieties of Capitalism and Economic Performance in Central and Eastern Europe, Palgrave Macmillan, New York.

CROISSANT, A., LAUTH, H.-J., MERKEL, W., H.-J. P. (2000), Zivilgesellschaft und Transformation: ein internationaler Vergleich, in: MERKEL W. (ed.): Systemwechsel 5: Zivilgesellschaft und Transformation, Opladen, Leske und Budrich, pp. 9-50.

CSABA, L. (ed.) (1994), Privatization, Liberalization and Destruction: Recreating the Market in Central and Eastern Europe, Aldershot, Brookfield a.o., Dartmouth.

CZEPCZYFRNSKI, M. (2008), Cultural Landscapes of Post-Socialist Cities: Representation of Powers and Needs, Aldershot, Burlington VT, Ashgate.

DELHEY, J. (2001), Osteuropa zwischen Marx und Markt: Soziale Ungleichheit und soziales Bewusstsein nach dem Kommunismus, Hamburg, Krämer (Beiträge zur Osteuropaforschung, 4).

DIETZ, B. (2002), East West Migration Patterns in an Enlarging Europe: The German Case, The Global Review of Ethnopolitics, no. 2 (1), pp. 29-43.

DIMITROVOVA, B., O'DOWD, L., SCOTT, J., W. (2007), Cross-Sectional Analysis Working Paper: Mapping Civil Society between Local Transformations and the European "Neighbourhood" (available at http://www.eudimensions.eu/content/publications/download/1st\% 20CSA\%20Report.pdf, accessed 4 Okt 2010).

DOSTÁL, P. (2008), The Post-Communist Capital City Effects: Transactional Activities and Regional Development in the Czech Republic in the 1990s. A Modelling Approach, in: STRUBELT W., GORZELAK G. (eds.): City and Region: Papers in Honour of Jiri Musil, Opladen, Budrich UniPress, pp. 15-42.

DUKE, V., GRIME, K. (1997), Inequality in Post-communism, Regional Studies, no. 37 (9), pp. 883-890.

ESKELINEN, H., LIIKANEN, I., OKSA, J. (eds.) (1998), Curtains of Iron and Gold: Reconstructing Borders and Scales of Interaction, Aldershot, Brookfield, Ashgate.

EYAL, G., SZELÉNYI, I., TOWNSLEY, E. (1998), Making Capitalism Without Capitalists: The New Ruling Elites in Eastern Europe, London, New York, Verso.

FASSMANN, H. (Wien), Immobilien-, Wohnungs- und Kapitalmärkte in Ostmitteleuropa: Beiträge zur regionalen Transformationsforschung (ISR-Forschungberichte, 14).

FASSMANN, H. (1997), Unemployment in East-Central Europe and its Consequences for East-West Migration, in: BLOTEVOGEL H. H., FIELDING A. J. (eds.): People, Jobs and Mobility in the New Europe, Chichester, New York, Wiley, pp. 169-186.

FISCHER, S., PLEINES, H. (eds.) (2010), Civil society in Central and Eastern Europe, Stuttgart, Ibidem-Verlag.

FODOR, É., BALOGH, A. (2010), Back to the kitchen?: Gender role attitudes in 13 East European countries, Zeitschrift für Familienforschung, no. 22 (3), pp. 289-307.

FRANZ, P. (2000), Soziale Ungleichheit und Stadtentwicklung in ostdeutschen Städten, in: HARTH A., SCHELLER G., TESSIN W. (eds.): Stadt und soziale Ungleichheit, Opladen, Leske und Budrich, pp. 160-173.

FRANZ, P. (2004), Schrumpfende Städte - schrumpfende Wirtschaft?: Der Fall

Ostdeutschland, Deutsche Zeitschrift für Kommunalwissenschaften, no. 32 (1), pp. 33-50.

FREJKA, T. (ed.) (1996), International Migration in Central and Eastern Europe and the Commonwealth of Independent States, New York, Geneva, United Nations (United Nations Economic Commission for Europe, United Nations Population Fund, Economic Studies, 8).

GABANYI, U., A. (1998), Systemwechsel in Rumänien: Von der Revolution zur

Transformation, München, Oldenbourg (Untersuchungen zur Gegenwartskunde Südosteuropas, 35).

GÁBOR, I. (1997), Too Many too Small: Small Entrepreneurship in Hungary - Ailing or Prospering? in: GRABHER G., STARK D. (eds.): Restructuring Networks in Post-Socialism: Legacies, Linkages, and Localities, Oxford, Oxford University Press, pp. 158-175. 
From Transformation to Idiosyncratic Modernisation: Shifting Analytical Perspectives on the Re-shaping of Central East and East Europe

GANS-MORSE, J. (2004), Searching for Transitologists: Contemporary Theories of Post -Communism and the Myth of a Dominant Paradigm, Post-Soviet Affairs, no. 20 (4), pp. 320349.

GOLDFARB, J., C. (1997), Why is There No Feminism After Communism?, Social Research, no. 64 (2), pp. 235-258.

GÓRZELAK, G. (1996), The Regional Dimension of Transformation in Central Europe, London, Bristol, Cromwell Press (Regional Policy \& Development Series, 10).

GÓRZELAK, G. (2000), Decentralization, Regional Development and Regional Politics, Informationen zur Raumentwicklung (7/8), pp. 349-359.

GRABHER, G. (1992), Eastern "Conquista": The Truncated Industrialisation of Eastern European Regions by Large Western-European Corporations, in: ERNSTE H., MEIER V. (eds.): Regional Development and Contemporary Industrial Response: Extending Flexible Specialisation, London, New York, Belhaven Press, pp. 219-232.

GRABHER, G. (1994a), Instant-Capitalism: Fragile Investment in Eastern German

Regions, in: DICKEN P., QUEVIT M. (eds.): Transnational Corporations and European Regional Restructuring, Utrecht, pp. 109-130 (Netherlands Geographical Studies, 181).

GRABHER, G. (1994b), The Elegance of Incoherence: Institutional Legacies,

Privatization and Regional Development in East Germany and Hungary, Berlin (Wissenschaftszentrum Berlin für Sozialforschung, Discussion Paper FS I 94-103).

GRABHER, G., STARK, D. (1997a), Organizing Diversity in Post-Socialism: Evolutionary Theory, Network Analysis, and Post-Socialism, in: GRABHER G., STARK D. (eds.): Restructuring Networks in Post-Socialism: Legacies, Linkages, and Localities, Oxford, Oxford University Press, pp. 1-32.

GRABHER, G., STARK, D. (1997b), Restructuring Networks in Post-Socialism: Legacies, Linkages, Localities, Oxford, Oxford University Press.

HALL, P., A., SOSKICE, D. (2001), An Introduction into Varietes of Capitalism, in: HALL

P. A., SOSKICE D. (eds.): Varieties of Capitalism: The Institutional Foundations of Comparative Advantage, Oxford, New York, Oxford University Press, pp. 1-68.

HAMILTON, F., E., I., ANDREWS, K., D., PICHLER-MILANOVIC, N. (eds.) (2005),

Transformation of Cities in Central and Eastern Europe: Towards Globalization, Tokyo, United Nations University. Schiler. HANNEMANN, C. (2005), Die Platte: Industrialisierter Wohnungsbau in der DDR, Berlin,

HAUSNER, J., JESSOP, B., NIELSEN, K. (1995), Strategic Choice and PathDependency in Post-Socialism: Institutional Dynamics in the Transforming Process, Aldershot, Elgar.

HEIDENREICH, M. (2005), The renewal of regional capabilities: Experimental regionalism in Germany, Research Policy, no. 34 (5), pp. 739-757.

HELLER, W. (1998), Romania: Migration, Socio-economic Transformation and Perspectives of Regional Development, München, Südosteuropa-Gesellschaft (SüdosteuropaStudien, 62).

HELLER, W. (2004), Ethnizität und Globalisierung: Bedeutungswandel ethnischer Kategorien in Transformationsländern, Geographische Zeitschzrift, no. 91 (1/2), pp. 21-38.

HELLER, W., IANOŞ, I. (2004), Spatial Patterns of Economy and Migration in Post-

Socialist Romania, Europa regional, no. 12 (1), pp. 4-12.

HEYNS, B. (2005), Emerging Inequalities in Central and Eastern Europe, Annual

Review of Sociology, no. 31, pp. 163-197.

HIGLEY, J., LENGYEL, G. (eds.) (2000), Elites after State Socialism: Theories and Analysis, Lanham ML, Oxford, Rowman \& Littlefield.

HOPFMANN, A. (1993), (Alp)Traum Systemtransformation: "Evolutionäre Universalien" und die Reformrealitäten in Mittel- und Osteuropa, Utopie kreativ (33/34), pp. 17-33. 
JALOWIECKI, B. (2008), Metropolisation of Polish Space, in: STRUBELT W., GORZELAK G. (eds.): City and Region: Papers in Honour of Jiri Musil, Opladen, Budrich UniPress, pp. 145-156.

KOLLMORGEN, R. (1994), Auf der Suche nach Theorien der Transformation: Überlegungen zu Begriff und Theoretisierung der postsozialistischen Transformation, Berliner Journal für Soziologie, no. 4, pp. 381-398.

KOLLMORGEN, R. (2005), Ostdeutschland: Beobachtungen einer Übergangs- und Teilgesellschaft, Wiesbaden, VS Verlag für Sozialwissenschaften.

KORKUT, U. (2005), The Relationship between Democratisation and the Invigoration of Civil Society in Hungary, Poland and Romania, PhD Thesis, Prague.

KORNAI, J. (2006), The great transformation of Central Eastern Europe: Success and Disappointment, Economics of Transition, no. 14 (2), pp. 207-244.

KRÄTKE, S. (1996), Where East Meets West: The German-Polish Border Region in Transformation, European Planning Studies, no. 4 (6), pp. 647-669.

KRÄTKE, S. (1997), Regionalstrukturen Ostmitteleuropas im Transformationsprozeß, Prokla, no. 27 (2 (107)), pp. 291-316.

KRÄTKE, S., HEEG, S., STEIN, R. (1997), Regionen im Umbruch: Probleme der Regionalentwicklung an den Grenzen zwischen "Ost" und "West", Frankfurt/M., New York, Campus.

KRÄTKE, S., SCHEUPLEIN, C. (2001), Produktionscluster in Ostdeutschland: Methoden der Identifizierung und Analyse, Hamburg, VSA-Verlag.

LADÁNYI, J. (2002), Residential Segregation among Social and Ethnic Groups in Budapest during the Post-communist Transition, in: MARCUSE P., VAN KEMPEN R. (eds.): Of States and Cities: The Partitioning of Urban Space, New York, Oxford University Press, pp. 170 -182 .

LANE, D. (2005), Revolution, class and globalisation in the transition from state socialism, European Societies, no. 7 (7), pp. 131-155.

LEWIS, P. (1997), Political Participation in Post-Communist Democracies, in: POTTER D. S. G. D., KILOH M., LEWIS P. (eds.): Democratization, Cambridge, Polity Press, pp. 443465 .

LIPSET, S., M. (1959), Some Social Requisites of Democracy: Economic Development and Political Legitimacy, The American Political Science Review, no. 53 (1), pp. 69-105.

LOWE, S., TSENKOVA, S. (eds.) (2003), Housing Change in East and Central Europe: Integration or Fragmentation? Aldershot, Ashgate.

LUTZ, B. (2003), Verpasste Gelegenheiten und nachzuholende Lektionen: Einige (selbst-)kritische Überlegunen zur deutschen Transformationsforschung der 90er Jahre, in: BRUSSIG M., ETTRICH F., KOLLMORGEN R. (eds.): Konflikt und Konsens: Transformationsprozesse in Ostdeutschland, Opladen, Leske und Budrich, pp. 287-305.

MANSFELDOVÁ, Z., SABÓ, M. (2000), Zivilgesellschaft im Transformationsprozeß OstMitteleuropas: Ungarn, Polen und die Tschechoslowakei, in: MERKEL W. (ed.): Systemwechsel 5: Zivilgesellschaft und Transformation, Opladen, Leske und Budrich, pp. 89114.

MANSOOR, A., QUILLIN, B. (eds.) (2006), Migration and Remittances: Eastern Europe and the Former Soviet Union, Washington DC, World Bank.

MATTHIESEN, U. (ed.) (2002), An den Rändern der deutschen Hauptstadt: Suburbanisierungsprozesse, Milieubildungen und biographische Muster in der Metropolregion Berlin-Brandenburg, Opladen, Leske und Budrich.

MATTHIESEN, U., BÜRKNER, H.-J. (2001), Antagonistic Structures in Border Areas: Local Milieux and Local Politics in the Polish-German Twin City Gubin/Guben, GeoJournal, no. 54, pp. 43-50. 
From Transformation to Idiosyncratic Modernisation: Shifting Analytical Perspectives on the Re-shaping of Central East and East Europe

MERKEL, W. (ed.) (1994), Systemwechsel 1: Theorien, Ansätze und Konzeptionen, Opladen, Leske und Budrich.

MERKEL, W. (1999), Systemtransformation: Eine Einführung in die Theorie und Empirie der Transformationsforschung, Opladen, Leske und Budrich (UTB für Wissenschaft: Uni-Taschenbücher, 2076).

MÜLLER, K. (1995), From Post-Communism to Post-Modernity?: Economy and Society in Eastern European Transformations, in: GRANCELLI B. (ed.): Social Change and Modernization: Lessons from Eastern Europe, Berlin, New York, Walter de Gruyter, pp. 265-293.

MÜLLER, K. (1996), Kontingenzen der Transformation, Berliner Journal für Soziologie, no. 6 (4), pp. 449-466.

MURRELL, P. (1993), What Is Shock Therapy?: What Did It Do in Poland and Russia?, Post-Soviet Affairs, no. 2, pp. 111-140.

NAGY, E. (2005), Urban development in post-transition Hungary: Emerging social conflicts as constraints for a locality, Geographia Polonica, no. 78 (1), pp. 23-38.

NUHN, H. (ed.) (2001), Systemtransformation und Regionalentwicklung: Technologiecluster der Mikroelektronik in Ostdeutschland, Münster, Lit.

OSWALT, P. (ed.) (2005), Shrinking Cities: Volume 1: International Research, Ostfildern -Ruit, Hatje Cantz.

OTT, N., WAGNER, G. (1997), Income inequality and poverty in eastern and western Europe, Heidelberg, Physica-Verlag.

OUTHWAITE, W., L., R. (2005), Social Theory and Postcommunism, Malden, Oxford,

Carlton, Blackwell.

PARSONS, T. (1967), Sociological Theory and Modern Society, New York, Free Press.

PERKMANN, M. (2005), Cross-border Co-operation as Policy Entrepreneurship: Explaining the Variable Success of European Cross-border Regions, University of Warwick, Warwick (CSGR Working Paper, 166/05; available at http://wrap.warwick.ac.uk/1953/1/ WRAP_Perkmann_wp16605.pdf; accessed 10 Jan 2011).

PETER, L. (1994), Kritische Anmerkungen zur modernisierungstheoretischen Interpretation des Umbruch- und Transformationsprozesses in Ostdeutschland, BISS public, no. 4 (13), pp. 11-20.

PHILIPOV, D., DORBRITZ, J. (2003), Demographic Consequences of Economic Transition in Countries of Central and Eastern Europe, Strasbourg, Council of Europe Publishing (Population Studies, 39).

PICKLES, J., SMITH, A. (eds.) (1998), Theorising Transition: The Political Economy of Post-Communist Transformation, London, New York, Routledge.

PIETERSE, J. N. (2003), Globalization and Culture: Global Mélange, Lanham, MD, Rowman \& Littlefield.

POLLACK, D. (1996), Sozialstruktureller Wandel, Institutionentransfer und die Langsamkeit der Individuen: Untersuchungen zu den ostdeutschen Transformationsprozessen in der Kölner Zeitschrift für Soziologie und Sozialpsychologie, der Zeitschrift für Soziologie und der Sozialen Welt, Soziologische Revue, no. 19 (4), pp. 412-429.

PRIDHAM, G. (2007), Romania and EU membership in comparative perspective: A post -accession compliance problem?: The case of political conditionality, Perspectives on European Politics and Society, no. 8 (2), pp. 168-188.

RAY, L. (1997), Post-Communism: Postmodernity or Modernity Revisited?, The British Journal of Sociology, no. 48 (4), pp. 543-560.

RIETDORF, W. (1997), Genesis, Status und Perspektive ostdeutscher Großsiedlungen, in: RIETDORF W. (ed.): Weiter wohnen in der Platte: Probleme der Weiterentwicklung großer Neubauwohngebiete in den neuen Bundesländern, Berlin, Edition Sigma, pp. 11-57.

ROBERTS, K. (2003), Change and continuity in youth transitions in Eastern Europe: Lessons from Western Sociology, The Sociological Review, no. 51 (4), pp. 484-505. 
ROMAN, D. (2007), Fragmented Identities: Popular Culture, Sex, and Everyday Life in Postcommunist Romania, Plymouth, Lexington Books.

ROSENBERG, N., BIRDZELL, L., E., JR. (1986), How the West Grew Rich: The Economic Transformation of the Industrial World,1987 Bände, New York, Basic Books.

RUDOLPH, H. (1995), Geplanter Wandel, ungeplante Wirkungen: Handlungslogiken und -ressourcen im Prozeß der Transformation, Berlin, Edition Sigma (WZB-Jahrbuch 1995).

SAGAN, I. (2009), Regions, New Regionalism and Regime Theory: Deciphering Post-

Socialist Institutional Change, in: SCOTT J. W. (ed.): De-coding New Regionalism: Shifting Socio-political Contexts in Central Europe and Latin America, Farnham, Burlington, Ashgate, pp. 93-112 (Urban and Regional Planning and Development Series).

SCHIMMELFENNIG, F., SEDELMEIER, U. (2004), Introduction: Conceptualizing the Europeanization of Central and Eastern Europe, in: SCHIMMELFENNIG F., SEDELMEIER U. (eds.): The Europeanization of Central and Eastern Europe, Ithaca, NY, Cornell University Press, pp. 1-28.

SCHMITTER, P., C., KARL, T., L. (1991), Modes of Transition in Latin America, Southern and Eastern Europe, International Social Science Journal, no. 129, pp. 269-284.

SCOTT, J., W. (ed.) (2006), EU Enlargement, Region-building and Shifting Borders of Inclusion and Exclusion, Aldershot, Ashgate (Ashgate Border Regions Series).

SCOTT, J., W., COLLINS, K. (1997), Inducing Transboundary Regionalism in Asymmetric Situations: The Case of the German-Polish Border, Journal of Borderland Studies, no. $12(1 / 2)$, pp. 97-121.

SCOTT, J., W., LIIKANEN, I. (2010), Civil Society and the 'Neighbourhood' Europeanization through Cross-Border Cooperation?, European Integration, no. 32 (5), pp. 423 -438 .

SEIBEL, W. (1997), Privatization by Means of State Bureaucracy?: The Treuhand Phenomenon in Eastern Germany, in: GRABHER G., STARK D. (eds.): Restructuring Networks in Post-Socialism: Legacies, Linkages, and Localities, Oxford, Oxford University Press, pp. 284-304.

SMIGIEL, C. (ed.) (2009), Gated and guarded housing in Eastern Europe, Leipzig, Institut für Länderkunde (Forum IfL, 11).

SMITH, A., PICKLES, J. (1998), Theorising transition and the political economy of transformation. in: PICKLES J., SMITH A. (eds.): Theorising Transition: The Political Economy of Post-Communist Transformation, London, New York, Routledge, pp. 1-22.

SMITH, A., SWAIN, A. (1998), Regulating and institutionalising capitalisms: The micro-foundations of transformation in Eastern and Central Europe, in: PICKLES J., SMITH A. (eds.): Theorising Transition: The Political Economy of Post-Communist Transformation, London, New York, Routledge, pp. 25-53.

SMITH, G. (1999), The Post-Soviet States: Mapping the Politics of Transition, London, Sydney, Auckland, Arnold.

SMITH, S. (2003), Local communities and post-communist transformation: Czechoslovakia, the Czech Republic and Slovakia, London, Routledge.

STANILOV, K. (2007), The Post-Socialist City: Urban Form and Space Transformations in Central and Eastern Europe after Socialism, Dordrecht, Springer (The GeoJournal Library, 92).

STARK, D. (1996), Recombinant property in East European capitalism, American Journal of Sociology, no. 101 (4), pp. 993-1027.

STEIN, J., P. (ed.) (2000), The Politics of National Minority Participation in PostCommunist Europe: State-Building, Democracy and Ethnic Mobilization, Armonk NY, M. E. Sharpe.

STEINFÜHRER, A., HAASE, A. (2007), Demographic Change as a Future Challenge for Cities in East Central Europe, Geografiska Annaler, no. 89 (2), pp. 183-195. 
STENNING, A. (2005), Post-Socialism and the Changing Geographies of the Everyday in Poland, Transactions of the Institute of British Geographers, no. 30 (1), pp. 113-127.

STENNING, A., HÖRSCHELMANN, K. (2008), History, Geography and Difference in the Post-socialist World: Or, Do We Still Need Post-Socialism?, Antipode, no. 40 (2), pp. 312-335.

STÖLTING, E. (1997), Wandel und Kontinuität der Institutionen: Rußland - Sowjetunion - Rußland, in: GÖHLER G. (ed.): Institutionenwandel, Opladen, Westdeutscher Verlag, pp. 181 -203 (Leviathan, Sonderheft 16).

SÝKORA, L. (2005), Gentrification in postcommunist cities, in: ATKINSON R., BRIDGE G. (eds.): Gentrification in a Global Context: The New Urban Colonialism, Milton Park, New York, Routledge, pp. 90-105.

SÝKORA, L. (2008), Revolutionary Change, Evolutionary Adaptation and New Path Dependencies: Socialism, Capitalism and Transformations in Urban Spatial Organizations, in: STRUBELT W., GORZELAK G. (eds.): City and Region: Papers in Honour of Jiri Musil, Opladen, Budrich UniPress, pp. 283-296.

SÝKORA, L. (2009), New socio-spatial formations: places of residential segregation and separation in Czechia, Tijdschrift voor Economische en Sociale Geografie, no. 100 (4), pp. 417-435.

SZELÉNYI, I. (2001), Poverty, ethnicity, and gender in transitional societies introduction, Review of Sociology, no. 7 (2), pp. 5-10.

SZELÉNYI, I., SZELÉNYI, S. (1995), Circulation or reproduction of elites during the postcommunist transformation of Eastern Europe, Theory and Society, no. 24 (5), pp. 615-638.

TATUR, M. (2004), Introduction: Conceptualising the Analysis of "Making Regions" in Post-socialist Europe, in: TATUR M. (ed.): The Making of Regions in Post-Socialist Europe the Impact of Culture, Economic Structure and Institutions, Wiesbaden, VS Verlag für Sozialwissenschaften, pp. 15-48.

THOMAS, M. (2008), Transformation - Hypertransformation - Transformation?: Drehen wir uns nur im Kreis? Anmerkungen zu einer berechtigten Fragestellung, Frankfurt/M., Peter Lang (Görlitzer Beiträge zu regionalen Transformationsprozessen, 3).

VERMEERSCH, P. (2003), Ethnic minority identity and movement politics: The case of the Roma in the Czech Republic and Slovakia, Ethnic and Racial Studies, no. 26 (5), pp. 879-901.

WIESENTHAL, H., BEYER, J., WIELGOHS, J. (2001), Introduction: Postcommunism as an Example of Successful Large-Scale Reform, in: BEYER J. W. J., WIESENTHAL H. (eds.): Successful Transitions: Political Factors of Socio-Economic Progress in Postsocialist Countries, Baden-Baden, Nomos Verlagsgesellschaft, pp. 7-22.

WITTE, J., C., WAGNER, G., G. (1995), Declining Fertility in East Germany After Unification: A Demographic Response to Socioeconomic Change, Population and Development Review, no. 21 (2), pp. 387-397.

WOLFE, T., C. (2000), Cultures and Communities in the Anthropology of Eastern

Europe and the Former Soviet Union, Annual Review of Anthropology, no. 29, pp. 195-216. ZAPF, W. (1994), Zur Theorie der Transformation, BISS public, no. 4 (13), pp. 5-19.

Initial submission, September 15, 2010

Revised submission, June 6, 2011

Final acceptance, November 30, 2011

Correspondence: Institute of Geography, University of Potsdam, Karl-Liebknecht-Straße 24/25, Haus 9, Zimmer 2.12, Potsdam (Golm), Germany, 14476.

E-mail: buerkner@uni-potsdam.de 
